\title{
Spatial Distribution of Plant-Associated Invertebrates and Environmental Bioassessment in a Natural Riverine Lake (Lake Fibreno, Centrall Italy)
}

\author{
Luciana Mastrantuono, Valentina Di Vito, Marcello Bazzanti \\ Department of Environmental Biology, Sapienza University of Rome, Rome, Italy \\ Email: luciana.mastrantuono@uniroma1.it
}

Received 1 June 2014; revised 28 June 2014; accepted 15 July 2014

Copyright (C) 2014 by authors and Scientific Research Publishing Inc. This work is licensed under the Creative Commons Attribution International License (CC BY). http://creativecommons.org/licenses/by/4.0/

(c) (i) Open Access

\section{Abstract}

Lake Fibreno is a Mediterranean riverine lake located in Central Italy and fed by large flows of groundwater and characterized by the presence of a wide reed stand area and of the only floating island of the South Europe. It is enclosed in a Natural Reserve recognized as Special Area of Conservation (SAC-IT6050015) for the presence of habitats and species $(92 / 43 /$ EEC) of relevant scientific interest. In this paper, we compare the plant-associated meio-macrobenthic invertebrates among sites with different environmental characteristics. Both vegetation and invertebrates of Lake Fibreno were well diversified and abundant and were composed of a mixing of species typical of lentic and lotic waters. Our results show that a gradient of orthophosphate and nitrite contents and current velocity appeared to be the driver factors affecting the flora and fauna spatial distribution at the sampling sites. To obtain a bioassessment of the ecological quality of the vegetation zone, we compared the riverine Lake Fibreno with typical lentic lakes previously studied in Central Italy. We selected metrics, such as macrophyte belt extent and taxa richness, invertebrate species richness and Shannon diversity, ETOM (Ephemeropta + Trichoptera + Odonata + Mollusca), ETOC (Ephemeropta + Trichoptera + Odonata + Coleoptera) and LCrM (Large Crustacea + Mollusca). The comparison indicated a good ecological status of the vegetation zone of Lake Fibreno mainly due to the continuous washout effects (dilution and fast water removal) which reduce the nutrient content available for phytoplankton and maintain the high transparency and good oxygenation of the lake waters.

\section{Keywords}

Macrophytes, Meio- and Macroinvertebrates, Mediterranean Riverine Lake, Ecological Bioassessment 


\section{Introduction}

In most part of the world, the progressive deterioration of the freshwater ecosystems is dramatically increased in the last decades following to several anthropogenic activities, especially agricultural practices, urbanization and industrialization, but in these last years also climatic changes and hydro-morphological modifications have represented additional negative pressures on the ecological integrity of the freshwater resources [1]-[3]. All these disturbances led to a taxonomic and functional monotony of the benthic community and became the primary causes of loss of biodiversity in freshwater ecosystems.

In this view, the lake littoral is increasingly investigated as a representative of the lake-land transition area and the first zone to be influenced by several anthropogenic modifications [4] [5]. The alterations of the lake shoreline, including reed stand destruction, can dramatically reduce the aquatic macrophyte biomass and taxonomic richness [6]. This modification negatively affects the invertebrate community, as they use plants as substrate for feeding, refuge and reproduction [7]-[10]. For these reasons, modifications caused by water quality changes determine a destabilization of the benthic community, involving not only loss of species richness but also variations of the community structure and trophic chain [11]-[15].

On the contrary, as the lake littoral is the area characterized by the highest invertebrate species richness, its conservation is fundamental as the representative of the main reserve of biodiversity for the entire freshwater system. Just in the light of the European Water Framework Directive [16], which included macroinvertebrates in the ecological classification of freshwater systems, it's of fundamental importance to continue in the development of monitoring projects which support the action of control and safeguard of freshwaters.

In Italy, and especially in the Latium region, the knowledge about plant-associated invertebrates has concerned so far typical lentic lakes [17]-[25] as it refers to both fauna composition and relations with environmental quality in littoral waters, so it appeared important to extend the studies also at different lacustrine ecosystems as the riverine Lake Fibreno to obtain a more complete picture of the biological characters of this geographic area.

Lake Fibreno is a very interesting example of lotic-lentic freshwater system for a consistent flow of groundwater, for its physico-chemical characteristics and for the presence of a very wide reed stand area and of the only floating island of the South Europe [26]. It is also a unique environment for the presence of the rare fish species Salmo macrostigma and Salmo fibreni, and latter probably an endemic species [27] [28]. Previous studies on Lake Fibreno refer only to plant composition and chemical parameters of the waters [29] [30], but no data were available on plant-associated invertebrates. All these peculiar lake characteristics and the very few studies on this biotope type suggested the opportunity to carry out this investigation with the following aims: 1) to know the biodiversity and spatial distribution of meioinvertebrates and macroinvertebrates associated with aquatic vegetation in such rare and less studied freshwater ecosystems in the Mediterranean region; 2) to evidence possible relationships between faunal composition and environmental site characteristics within the lake; 3) to define the lake ecological status in the littoral throughout some bioindicators and bioindices with a comparison of studies dealing with other central Italian lakes. The importance of this work increases if we consider the few existing studies dealing with the meiobenthic elements generally ignored in benthological studies often restricted to macroinvertebrates.

\section{Study Area and Methods}

Lake Fibreno, located at 289 m.a.s.l., has a perimeter of $4850 \mathrm{~m}$, a surface area of $0.277 \mathrm{~km}^{2}$ (max. length: 1750 m; max. width: $320 \mathrm{~m}$ ), a maximum depth of $15 \mathrm{~m}$ (mean depth: $2.7 \mathrm{~m}$ ) and an invaded volume of $7476 \mathrm{~m}^{3}$. It is a spring-lake located in Central Italy. It is enclosed in a Natural Reserve recognized as Special Area of Conservation (SAC-IT6050015) for the presence of relevant habitats and species listed in annexes I and II of the European Union Directive on the Conservation of Natural Habitats and of Wild Fauna and Flora (92/43/EEC). The lake is the phreatic level of groundwater of a karstic environment of the Marsica hydrogeologic system, which extends in NW-SE Apennine direction. The water comes from a complex of submerged and surface springs of mineral-rich waters, distributed on a forehead of approximately $1 \mathrm{~km}$. The only effluent of the entire drainage basin is the Fibreno river, with a mean annual water discharge of $9.3 \mathrm{~m}^{3} \cdot \mathrm{s}^{-1}$, evaluated on the data set of the last 40 years. The karstic character of this area is highlighted by the presence of many sinkholes, some submerged and many others laying in the hills surround the lake itself. Most of the drainage basin is prone to sinkhole formation because it is under-lain by thick carbonate deposits that are susceptible to dissolution by circulating groundwater. The entire Fibreno plain is crossed by several narrow channels mainly colonized by Carex, 
and in the southern part of the lake (Figure 1) extends a wide area of about 50 hectars largely colonized by Phragmites australis, associated at the margins with Carex spp., Cirsium palustre, Menta acquatica, Caltha palustris, Epilobium palustre, Galium palustre and some others species [31].

Meio- and macrobenthic invertebrates were collected in six sites (Figure 1) characterized by different water flow regimes (because the water current velocity was not measured regularly, we determined this water parameter visually and we recognized four apparent typologies reported in the statistical analysis by numbers $1-4$ according to increasing speed water flow): spring areas (sites 1 and 2, speed water flow given as level 3), floating island (site 3, slow water flow given as level 1), large lake area (site 4, medium-speed water flow given as level 2), drainage ditch (site 5 , slow water flow given as level 1), riverine zone (site 6 , zone between the end of lake and first part of the Fibreno river, which collect water of Lake Fibreno drainage basin, very speed water flow given as level 4). Invertebrate samples were collected six times (bimonthly occasions) during one year (from February to November 2004) using a sledge dredge (size: $35 \times 20 \mathrm{~cm}$, mesh size: $180 \mu \mathrm{m}$ ) at depth ranges of $0-4 \mathrm{~m}$ and $10-15 \mathrm{~m}$ (this latter depth range only in the two deeper stations: 3 and 4). The dredge was dragged parallel to the shore at the selected depth range for about 20 meters following a sinusoidal patch in order to obtain numbers of collected individuals comparable between sites. The material was preserved in 5\% formaldehyde solution. Complete macroinvertebrate samples were sorted by a visual method, whereas meiobenthic organisms were separated into subsamples and sorted at low magnification under a stereomicroscope. All individuals were identified as far as possible at a species or genus level.

Macrophyte taxa were identified as far as possible at species level both visually and examining in the laboratory the specimens collected by the same samples used for invertebrates. Also plant abundance was evaluated visually using a 1 - 4 range, according to their abundance observed in the field and collected in the samples. Additional data on plant composition were provided by L. Casella (Dept. of Environmental Biology, Sapienza University of Rome) [32].

Water transparency was measured with a standard Secchi disk at the two deepest sites (stations 3 and 4) at the same dates of fauna sampling. Other physico-chemical analyses of lake surface waters were carried out by E. Agrillo (Department of Earth Sciences, Hydrogeological Laboratory, Sapienza University of Rome) at the same sampling sites and periods of the faunal study [32].

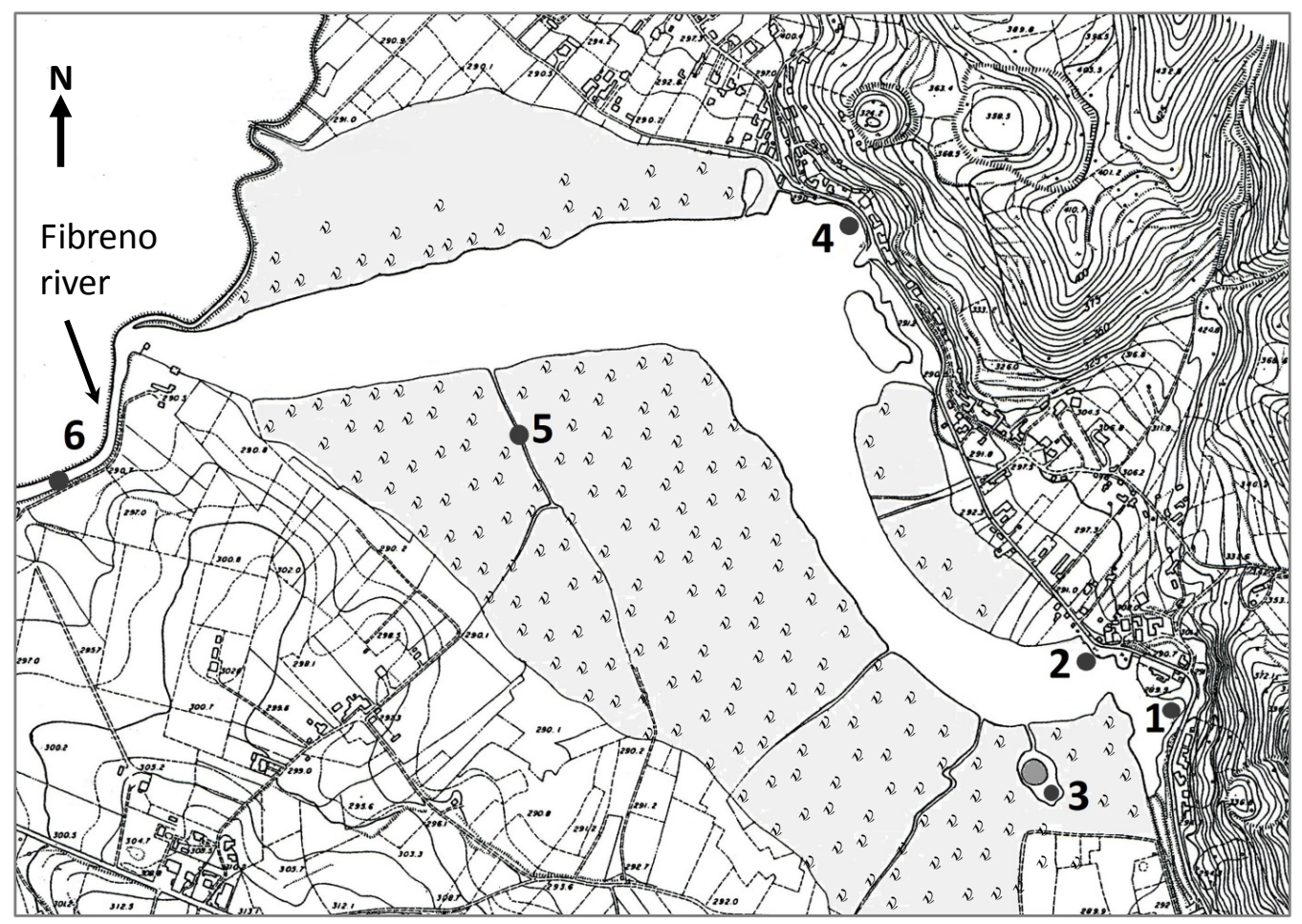

Figure 1. Map of Lake Fibreno and location of the sampling sites $(1-6)$. Site 3 corresponds to the floating island. The area colonized by reed stand is indicated with $\mathrm{v}$. 
Canonical Correspondence Analysis (CCA) was performed to correlate some abiotic characteristics with macrophyte and invertebrate taxa abundances separately. We performed the statistical analyses with the Vegan package for R software [33]. For invertebrate taxa abundances (expressed as annual mean values of collected organisms) were used only data of the $0-4 \mathrm{~m}$ depth range. Taxa collected with only one specimen during the study were excluded from the CCA analysis. Before the analyses, we transformed data of physico-chemical parameters (except $\mathrm{pH})$ in $\log x$ and abundances of invertebrate taxa in $\log (x+1)$, respectively, in order to stabilize the variance [34]. For macrophytes we used their class abundances at the six stations only for depth range 0 - $4 \mathrm{~m}$ with respect to the bottom cover as follows: $0=$ absent, $1=$ scarce $(1 \%-25 \%), 2=$ abundant $(26 \%$ $50 \%), 3$ = very abundant (51\% - 75\%) and $4=$ dominant (76\% - 100\%). Finally, the PSc index [35] was adopted to measure similarity among sampling sites using the percentages of invertebrate taxa. PSc values were represented by UPGMA clustering method [34].

\section{Results}

\subsection{Physico-Chemical Features}

According to its nature of a spring-lake, Lake Fibreno showed high annual mean values of water transparency (at sites $1-2$ and 5 - 6 the transparency reached always the bottom, while at the sites 3 and 4 it was $9.1 \mathrm{~m}$ and $12.3 \mathrm{~m}$, respectively), low and constant temperature $\left(10^{\circ} \mathrm{C}-11^{\circ} \mathrm{C}\right)$ and high oxygen content during the entire year (Table 1). The lake is yielded by calcium-bicarbonate groundwater aquifer due to the lithological characteristics of the area, so its hardness was high and $\mathrm{pH}$ close to neutrality. The high values of orthophosphates and nitrites (Table 1) come probably from some domestic discharges and agricultural activities around the lake. As reported in the Methods, the water flow velocity was very different among the sampling sites, varying from speed water flow (sites 1, 2 and 6) to slow water flow (sites 3 and 5).

\subsection{Aquatic Plant Spatial Patterns}

The aquatic plant community comprised a total of 11 taxa (Table 2). Quantitatively Callitriche hamulata, $C$. palustris and Hippuris vulgaris were the more abundant species, followed by Apium nodiflorum. Moreover, we observed an extensive reduction of Potamogeton colonization in comparison with past studies [28] [29], which reported a distribution of this plant on the entire lake. During the present study Potamogetonaceae have been found only in the Fibreno river, while most part of the central lake area is completely bared. Also more recent observations [31] confirmed a substantial reduction of the plant abundance in the last years. Moreover, a great bloom of the sulfum-bacterium Thiopedia rosea was also observed in late summer in a wide part of the bared bottom of the central lake area. Only in the deepest zones of the lake Chara sp. sparsely covered the bottom of stations 3 and 4 (called dolines) at about 12 and $15 \mathrm{~m}$ respectively.

CCA analysis performed on macrophyte abundances (Figure 2) showed some differences among the sampling sites according to the water flow regime and chemical compounds. The sites are positioned along the increasing gradient of orthophosphate content and decreasing of current velocity and nitrite concentration. Sites 1 and 2 were highly related to current velocity and nitrites vectors and were characterized by Apium nodiflorum (see taxa codified as in Table 3). Current velocity, nitrite concentration and oxygen content influence also site 6 (speed current flow) where Potamogeton sp. and Sparganium erectum were dominant. Sites 3 and 4 and secondarily site 5 (slow-medium water flow) were related with orthophosphate amount and were characterized by Hippuris vulgaris, Callitriche hamulata, C. palustris and Riccia fluitans.

\subsection{Invertebrate Composition and Spatial Distribution}

Data collected in this study supplies for the first time results on the meio-macrobenthic composition of Lake Fibreno. The faunal community was represented (Table 3 ) by a high number of groups (28 taxa up to the family level). The analysis at genus and/or species level provided the identification of 98 taxa, half of them belonging to oligochaetes (10), nematodes (10), gastropods (10) and chironomids (9), the remaining ones to hirudineans, insects, crustaceans and acari. Due the low abundance of vegetation in the deeper zones of sites 3 and 4 , also invertebrate taxa showed a strong reduction at major depths both in species richness ( 0 - $4 \mathrm{~m}$ : 96 taxa; 8 - 15 m: 36 taxa) and in abundances (annual mean number of counted individuals, 0 - $4 \mathrm{~m}$ : 61,946; 8 - $15 \mathrm{~m}$ : 4321) at these depths. 
Table 1. Annual mean values of physico-chemical parameters at the six sampling sites of Lake Fibreno in 2004 (Agrillo, unpublished data). Cond = Conductivity, TDS: total dissolved solids; TH: total hardness.

\begin{tabular}{cccccccccc}
\hline Sites & $\mathrm{pH}$ & $\begin{array}{c}\mathrm{T} \\
\left({ }^{\circ} \mathrm{C}\right)\end{array}$ & $\begin{array}{c}\mathrm{O}_{2} \\
(\mathrm{mg} / \mathrm{l})\end{array}$ & $\begin{array}{c}\mathrm{NO}_{3}^{-} \\
(\mathrm{mg} / \mathrm{l})\end{array}$ & $\begin{array}{c}\mathrm{PO}_{4}^{3-} \\
(\mu \mathrm{g} / \mathrm{l})\end{array}$ & $\begin{array}{c}\mathrm{TDS} \\
(\mathrm{mg} / \mathrm{l})\end{array}$ & $\begin{array}{c}\mathrm{Cond} \\
(\mu \mathrm{S} / \mathrm{cm})\end{array}$ & $\begin{array}{c}\mathrm{HCO}_{3}^{-} \\
(\mathrm{mg} / \mathrm{l})\end{array}$ & $\begin{array}{c}\mathrm{T} . \mathrm{H} . \\
\left({ }^{\circ} \mathrm{F}\right)\end{array}$ \\
\hline 1 & 7.06 & 10.2 & 10.1 & 2.4 & 107 & 355 & 624 & 425 & 37 \\
2 & 7.07 & 10.4 & 10.5 & 2.5 & 117 & 352 & 616 & 435 & 40 \\
3 & 7.14 & 10.4 & 10.6 & 2.2 & 82 & 343 & 601 & 402 & 35 \\
4 & 7.10 & 10.5 & 11.4 & 1.7 & 127 & 361 & 632 & 408 & 41 \\
5 & 7.28 & 11.3 & 11.5 & 1.8 & 148 & 345 & 611 & 412 & 37 \\
6 & 7.16 & 10.6 & 12.4 & 2.1 & 90 & 339 & 591 & 389 & 40 \\
\hline
\end{tabular}

Table 2. Distribution of aquatic vegetation in Lake Fibreno: $\bullet$ rare; $\bullet \bullet$ scarce; $\bullet \bullet \bullet$ abundant; $\bullet \bullet \bullet \bullet$ dominant (plant identification was partly supplied by Dr. L. Casella). Abbreviations: codes of taxa for CCA analysis.

\begin{tabular}{|c|c|c|c|c|c|c|c|c|}
\hline Sites & 1 & 2 & 3 & 4 & 5 & 6 & 3 & 4 \\
\hline Depth Ranges & $0-4 m$ & $0-4 m$ & $0-4 m$ & $0-4 m$ & $0-4 \mathrm{~m}$ & $0-4 m$ & $12 \mathrm{~m}$ & $15 \mathrm{~m}$ \\
\hline Chara sp. & & & & & & & $\bullet$ & $\bullet$ \\
\hline Riccia fluitans L. ric & & & & & $\bullet$ & & & \\
\hline Potamogeton sp. pot & & & & & & $\bullet \bullet$ & & \\
\hline Lemna sp. lem & & & & $\bullet$ & $\bullet$ & & & \\
\hline Sparganium erectum L. spa & & & & & & $\bullet \bullet \bullet$ & & \\
\hline Callitriche hamulata (Kütz) cal.h & $\bullet$ & $\bullet \bullet$ & $\bullet \bullet \bullet \bullet$ & $\bullet \bullet$ & $\bullet \bullet \bullet \bullet$ & $\bullet$ & & \\
\hline Callitriche palustris L. cal.v & $\bullet$ & $\bullet \bullet$ & $\bullet \bullet \bullet \bullet$ & $\bullet \bullet$ & $\bullet \bullet \bullet \bullet$ & $\bullet \bullet$ & & \\
\hline Hippuris vulgaris L. hip & $\bullet \bullet$ & $\bullet \bullet$ & $\bullet \bullet \bullet$ & $\bullet \bullet \bullet$ & $\bullet \bullet \bullet$ & & & \\
\hline Apium nodiflorum (L.) api & $\bullet \bullet \bullet \bullet$ & $\bullet \bullet \bullet \bullet$ & & $\bullet \bullet$ & & & & \\
\hline Veronica anagallis aquatica L. ver & $\bullet$ & $\bullet$ & $\bullet$ & $\bullet$ & & $\bullet$ & & \\
\hline Mentha aquatica L. men & & $\bullet$ & $\bullet$ & & & & & \\
\hline Total Number of Species: 11 & 5 & 6 & 5 & 6 & 5 & 5 & 1 & 1 \\
\hline
\end{tabular}

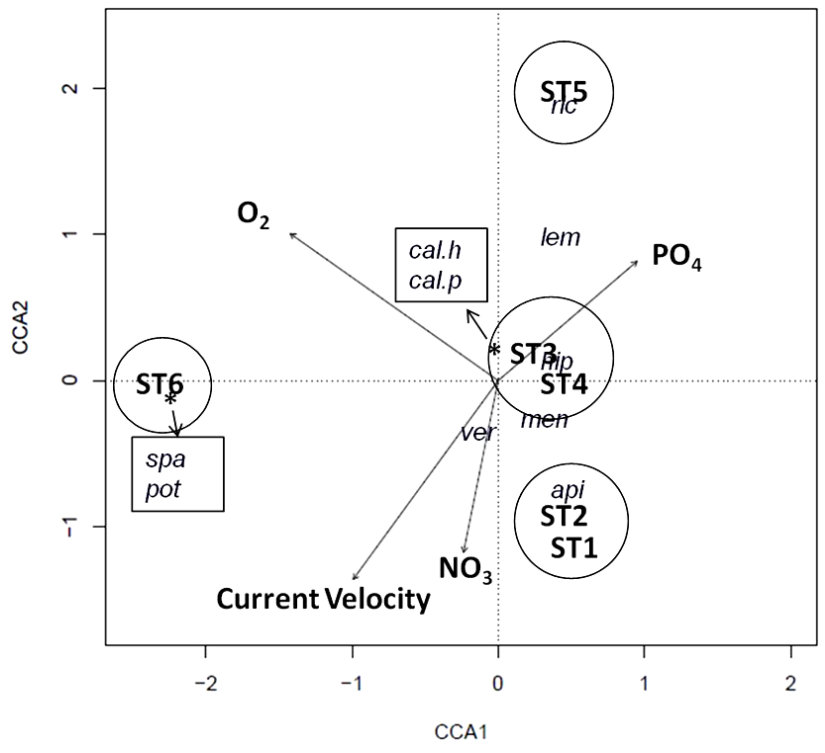

Figure 2. CCA plot of plant taxa, sampling sites and environmental parameters of Lake Fibreno. Explained variance: axis $1=$ $52.7 \%$, axis $2=24.5 \%$. Taxa are coded as in Table 2 . 
Table 3. List of taxa collected at two depth ranges in Lake Fibreno in 2004. The numerical values are the total number of individual found during the study. Abbreviations: codes of taxa for CCA analysis are reported.

\begin{tabular}{|c|c|c|c|c|c|}
\hline Depth ranges & $0-4 \mathrm{~m}$ & $8-15 m$ & & $0-4 \mathrm{~m}$ & $8-15 m$ \\
\hline Turbellaria & & & Diptera Chironomidae & & \\
\hline Dugesia tigrina (Girard) dugtr & 158 & 1 & Orthocladiinae indet. orthoc & 51,270 & 2019 \\
\hline Dendrocoelum sp. & 1 & 0 & Corynoneuracoryn & 3055 & 0 \\
\hline Polycelis sp. polyc & 35 & 0 & Procladius & 0 & 35 \\
\hline Nematoda & & & Tanypodinaeindet. tanyp & 1165 & 178 \\
\hline Monhistera filiformis (Bastian) monfi & 212 & 1555 & Tanytarsus tanyt & 2507 & 133 \\
\hline Aphanolaimus aquaticus (Daday) aphaq & 51 & 0 & Paratanytarsus parat & 6335 & 1130 \\
\hline Ethmolaimus pratensis De Man ethpr & 110 & 0 & Glyptotendipes glypto & 217 & 0 \\
\hline Plectus sp. plect & 428 & 0 & Chironomus chiron & 702 & 74 \\
\hline Tobrilus gracilis (Bastian) tobgr & 1198 & 152 & Parachironomus parach & 109 & 0 \\
\hline Tobrilus helveticus (Hofmänner) tobhe & 2064 & 165 & Diptera Ceratopogonidae & & \\
\hline Tobrilus longicauda (Linstow) toblon & 50 & 47 & Culicoidinae indet. culico & 43 & 0 \\
\hline Monochus truncatus (Bastian) montr & 1676 & 0 & Dasyhelea sp. dasyh & 350 & 0 \\
\hline Ironus tenuicaudatus (De Man) & 0 & 16 & Diptera Tipulidae & & \\
\hline Dorylaimina indet. doryl & 162 & 0 & Tipulidae indet. & 1 & 0 \\
\hline Oligochaeta & & & Diptera Simuliidae & & \\
\hline Chaetogaster diaphanus (Gruithuisen) chdiap & 79 & 25 & Simuliidae indet. simul & 10,733 & 0 \\
\hline Chaetogaster diastrophus (Gruithuisen) chdias & 319 & 477 & Diptera Ephydridae & & \\
\hline Ophidonais serpentina (Müller) ophse & 273 & 0 & Ephydridae indet. ephyd & 127 & 0 \\
\hline Stylaria lacustris (L.) styla & 11,878 & 643 & Diptera Alia diptal & 6 & 0 \\
\hline Nais simplex Piguet naisi & 2799 & 235 & Lepidoptera & & \\
\hline Nais pardalis Piguet naipa & 12 & 0 & Pyralidae & 1 & 0 \\
\hline Nais variabilis Piguet naiva & 3145 & 823 & Lepidoptera indet. & 1 & 0 \\
\hline Dero sp. dero & 669 & 0 & Trichoptera & & \\
\hline Potamothrix heuscheri (Bretscher) potheu & 431 & 181 & Rhyacophila simulatrix (?) Lachlan) & 3 & 0 \\
\hline Limnodrilus indet. tubif & 182 & 6 & Polycentropodidae indet. & 1 & 0 \\
\hline Hirudinea & & & Apatania sp. apata & 1176 & 0 \\
\hline Glossiphonia complanata (L.) glosco & 2 & 0 & Limnephilus sp. limnep & 2195 & 59 \\
\hline Glossiphonia sp. & 1 & 0 & Allogamus sp. allog & 0.3 & 0 \\
\hline Helobdella stagnalis (L.) & 1 & 0 & Plecoptera & & \\
\hline Hemiclepsis marginata (O.F. Müller) & 1 & 0 & Isoperla sp. isope & 495 & 0 \\
\hline Erpobdella octoculata (L.) erpoc & 3 & 3 & Coleoptera & & \\
\hline Erpobdella sp. & 1 & 0 & Orectochilus sp. orect & 7 & 0 \\
\hline Gnathobdellae indet. & 1 & 0 & Haliplus sp. halip & 147 & 19 \\
\hline Tardigrada & & & Hygrotussp. & 1 & 0 \\
\hline Tardigrada indet. tardig & 1600 & 0 & Agabussp. agab & 36 & 0 \\
\hline Cladocera & & & Elmissp. elmi & 121 & 9 \\
\hline Simocephalus vetulus (O.F. Müller) simvet & 17,556 & 16 & Scirtessp. scirt & 46 & 0 \\
\hline Pleuroxus aduncus (Jurine) pleadu & 216 & 0 & Donaciinae indet. donac & 35 & 0 \\
\hline Chydorus sphaericus (O.F. Müller) chysph & 3091 & 0 & Hydroporinae indet. hydrop & 31 & 0 \\
\hline Graptoleberis testudinaria (Fischer) grates & 5073 & 0 & Dytiscidaeindet. & 1 & 0 \\
\hline
\end{tabular}




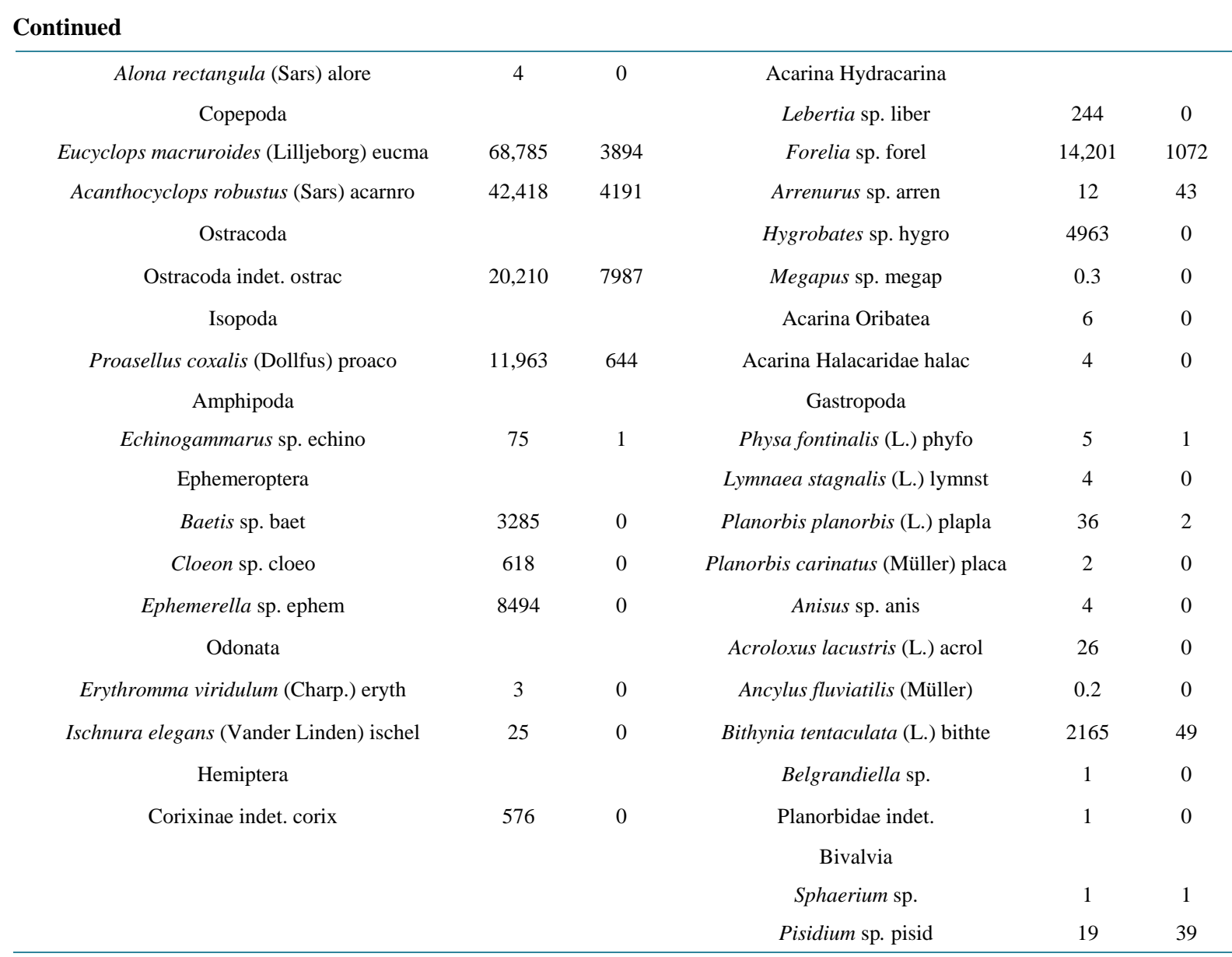

Quantitatively, copepods prevailed on the total fauna collected during the study (38\%). They were associated with chironomids, mites and ostracods (altogether 34\%), oligochaetes (6\%) and microfilterer cladocerans (7\%). A remarkable percentage of other invertebrates characterized the community (15\%, summarized as Alia). The percentages of zoological groups were different at the sampling sites (Figure 3). Sites 1 and 2, located close to spring waters and characterized by speed flow, displayed a very similar faunal composition with remarkable predominance of copepods followed by some chironomids. Sites 3 and 5, in the area of the floating island and of a ditch respectively, had lentic typology and a fauna dominated by some well partitioned zoological groups (copepods, some chironomids, cladocerans and Alia). Cladocerans, which need standing waters, reached their highest numbers at these sites (at site 3: annual mean number of 1664 individuals and percentage of $18 \%$ of total fauna; at site 5: annual mean number of 2133 individuals and 16.6\% of total fauna), while at sites 1, 2, 4 and 6 the range of annual mean number of individuals was 12 - 271 (0.07\% - 2.4\% of total fauna). At site 4 (mediumspeed flow) copepods were still largely dominant together with ostracods and acari. Site 6, which had a lotic character, clearly displayed a different faunal composition dominated mainly by some chironomids and other insect taxa such Diptera Simulidae and Tipulidae, Plecoptera, some Trichoptera, all summarized as Alia.

CCA on invertebrate data (Figure 4) indicates a clear position of the sites along an increasing gradient of orthophosphate content and decreasing of current velocity and nitrite concentration. Sites 5 and 3 were related to the lentic features of the environment (low water current speed and eutrophication effects), whereas sites 6, 1 and 2 resulted related to lotic characteristics of the lake (higher current speed and presence of nitrites). Taxa near each site (circled in Figure 4 and codified in Table 3) are considered as typical of that site. The results from the PSc analysis (Figure 5), where the percentages of taxa were used, showed the same similarity among the sites obtained from the CCA analysis which was based on absolute numbers. A clear separation between sites 1 - 2 (with speed water flow) and sites 3 - 5 (with slow water flow) can be observed. Site 6 (running water) was well separated from the other sites and site 4 was in an intermediate position due to its moderate current velocity. 


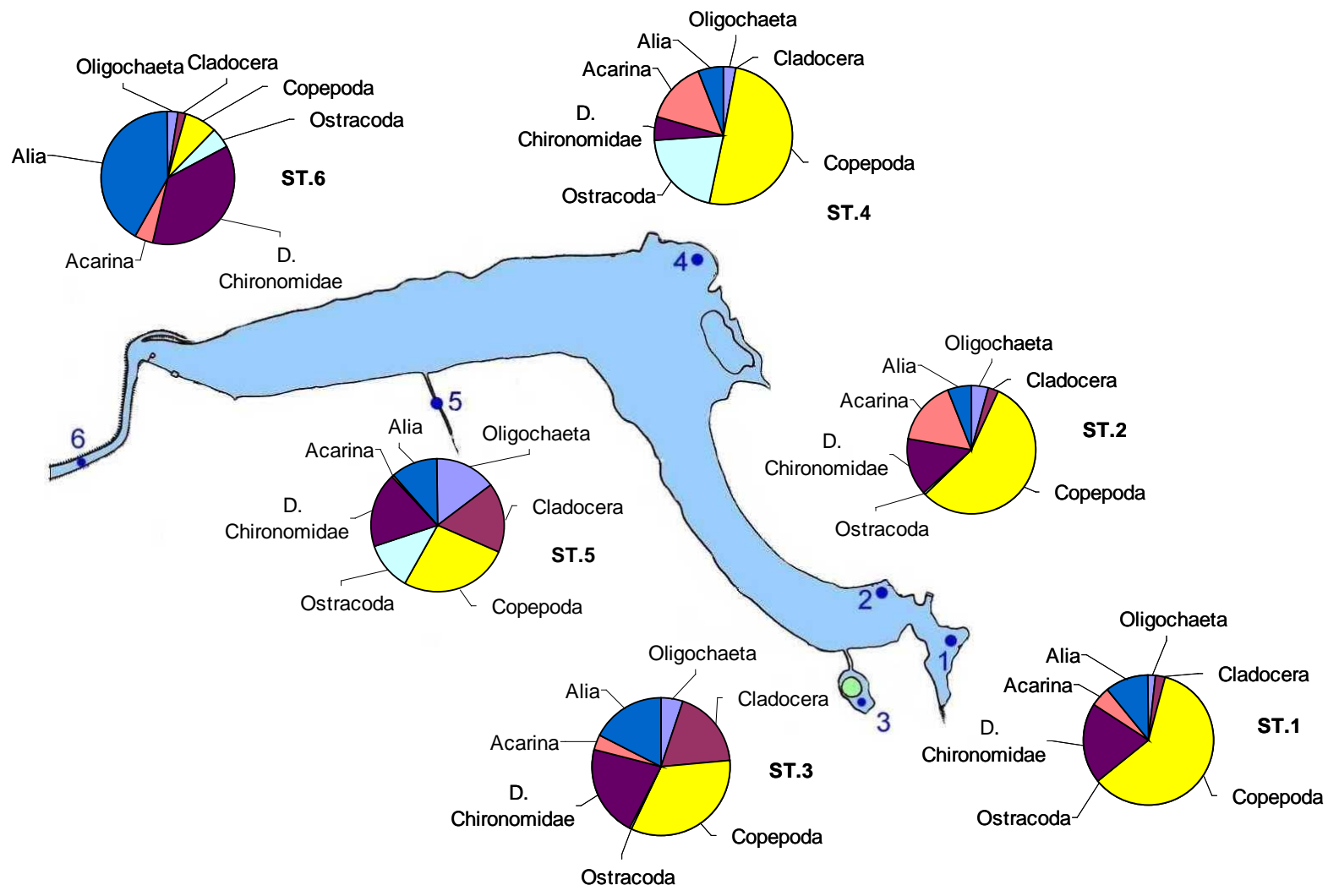

Figure 3. Percentage composition of the invertebrate fauna in the six sampling sites of Lake Fibreno.

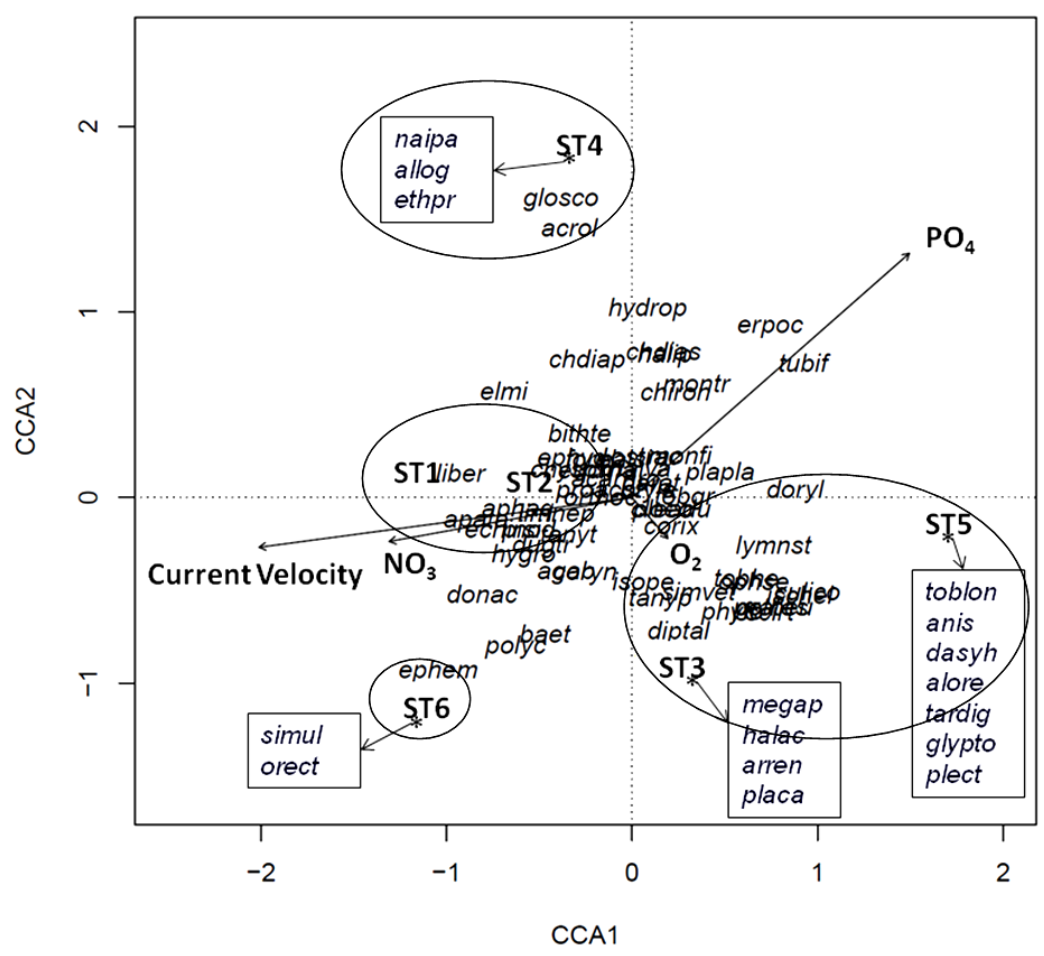

Figure 4. CCA plot of invertebrate taxa, sampling sites and environmental parameters of Lake Fibreno. Explained variance: axis $1=35.6 \%$. axis $2=26.9 \%$. Taxa are coded as in Table 3. 


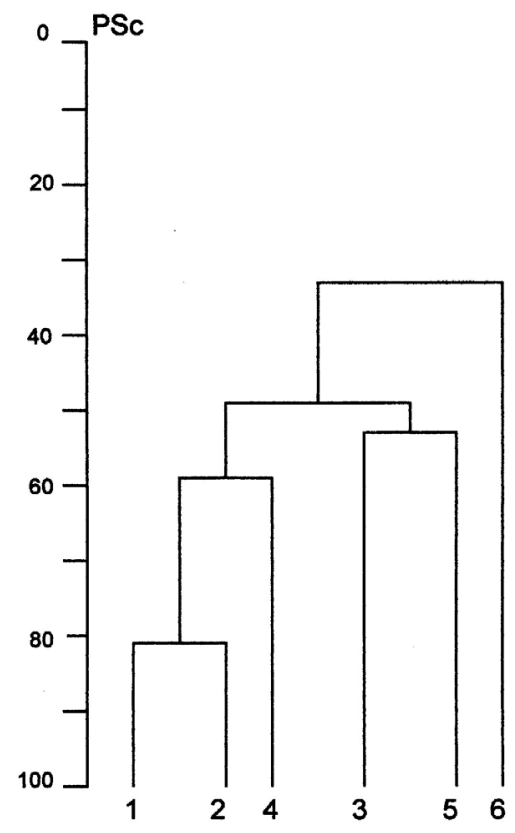

Figure 5. Cluster representation of PSc values between six sampling sites in Lake Fibreno.

\section{Discussion}

Our results indicate that the aquatic vegetation of Lake Fibreno appeared taxonomically diversified. CCA analysis showed a distribution of species within the sampling sites according to water current velocity and nutrient contents. Macrophyte assemblages clearly showed the presence of taxa typical of both stagnant and running waters [31], i.e. Lemna and Riccia are more typical of lentic waters, Callitriche spp. and Apium nodiflorum require cold and well oxygenated waters, and Sparganium erectum better characterizes lotic waters [36]. Some of them (Hippuris vulgaris, Apium nodiflorum and Chara sp.) are recognized as quite sensitive to environmental conditions [37].

It is well known that the high water transparency is a determinant factor for maintaining extensive plant distribution and abundance and consequently many invertebrate species. These aspects are fundamental for a good condition of a lake trough a feedback mechanism, because plant growth limits nutrient contents, prevents massive algal blooms, hinders sediment resuspension maintaining high water transparency and high oxygen content, and allows a rich biodiversity of communities [38]-[41]. Due to high water transparency, in Lake Fibreno the aquatic vegetation reached the maximum depth (Table 4) where it was represented by Charales which generally colonize the infralittoral deep zone of oligo-mesotrophic lakes and are sensitive to water quality deterioration [2] [42]-[45].

Also the benthic invertebrates of Lake Fibreno appeared to be well diversified, comprising a great number of high zoological groups and high species/genera richness similar to those found in the aquatic plant-substratum of other lakes in good environmental condition (Table 4). This richness is supported by the existence of varied microhabitats related to the lotic-lentic lake typology, and in particular by a fundamental role played by the wide reed stand which is a great biodiversity source for this ecosystem. The invertebrate assemblage was characterized by several taxa which can be considered indicators of good water quality, as the chironomid Orthocladiinae and Corynoneura sp. [46] [47], the Hydrobioidea Belgrandiella sp. [48], three families of trichopterans (Rhyacophilidae, Polycentropodidae, Limnephilidae), some ephemeropteran (Baetis, Cloeon, Ephemerella) and the plecopteran Isoperla [49]. Moreover 3\% of the total oligochaetes was represented by Stylaria lacustris, a typical species of oligo-mesotrophic waters [50].

Likely to vegetation CCA results, CCA on invertebrate community indicated that an increasing gradient of orthophosphate content and decreasing of current velocity and nitrite concentration at the sampling sites appeared to be the driver factors affecting also the invertebrate spatial distribution in the lake. Moreover, also the 
Table 4. Values of some bioindices of the invertebrates associated with submerged vegetation in some lakes of Central Italy and ecological status of the littoral vegetated area. Total fauna is expressed as annual mean number of invertebrates/number of stations/maximum depth colonized by aquatic plants. ETOM (Ephemeroptera + Trichoptera + Odonata + Mollusca), ETOC (Ephemeroptera + Trichoptera + Odonata + Coleoptera) and large LCrM (Large Crustacea + Mollusca). These three indices were calculated as both number of taxa and percentage of individuals on total invertebrate fauna. Lake trophic status (o = oligotrophy, $\mathrm{m}$ = mesotrophy, $\mathrm{m}-\mathrm{e}=$ meso-eutrophy, e-hy = eu-hypereutrophy) follows total phosphorus and water transparency parameters [51].

\begin{tabular}{cccccccccc}
\hline Lakes & Bracciano & Bracciano & Martignano & Vico & Fibreno & Nemi & Albano & Nemi \\
\hline Study year & 1998 & 2003 & 1996 & 1985 & 2004 & 2003 & 1986 & 1981 \\
\hline Maximum depth (m) & 165 & 165 & 60 & 48.5 & 15 & 32.4 & 175 & 32.4 \\
Vegetation belt (m) & $0-20 \mathrm{~m}$ & $0-20 \mathrm{~m}$ & $0-20 \mathrm{~m}$ & $0-20 \mathrm{~m}$ & $0-15 \mathrm{~m}$ & $0-8 \mathrm{~m}$ & $0-8 \mathrm{~m}$ & $0-4 \mathrm{~m}$ \\
Nr. of plant taxa & 9 & 9 & 9 & 13 & 11 & 9 & 9 & 5 \\
Species richness & 125 & 89 & 117 & 108 & 94 & 71 & 78 & 61 \\
H diversity (Shannon) & 4.1 & 3.4 & 3.3 & 3.6 & 3.9 & 3.4 & 3.2 & 2.2 \\
Total fauna & 1710 & 2345 & 1772 & 4974 & 2581 & 1264 & 3125 & 11,730 \\
ETOM (taxa richness) & 18 & 13 & 13 & 17 & 17 & 10 & 12 & 13 \\
ETOM (\%) & 5.9 & 4.5 & 1.2 & 1.4 & 4.9 & 1.7 & 0.8 & 0.2 \\
ETOC (taxa richness) & 9 & 6 & 7 & 10 & 16 & 7 & 8 & 11 \\
ETOC (\%) & 1.0 & 1.6 & 0.3 & 0.5 & 4,2 & 0.4 & 0.08 & 0.1 \\
LCrM (taxa richness) & 11 & 9 & 8 & 10 & 12 & 4 & 7 & 4 \\
LCrM (\%) & 5.2 & 3.5 & 1.0 & 1.0 & 4.8 & 1.3 & 0.7 & 0.1 \\
Ecological state of lake littoral & good & good & good & good & good & mod/good & mod & poor/bad \\
Lake trophic status & o & o & o & m & m-e & m-e & m-e & e-hy \\
Lowering of water level & & x & & & & x & & \\
\hline
\end{tabular}

fauna appeared as a mixing of taxa preferring lotic or lentic waters. Plecopterans, the dipteran Ephydridae, Tipulidae and Simulidae, the ephemeropteran Baetis, the gastropod Ancylus and the hirudinean Glossiphonia are frequently found in lotic waters [52] [53]. The similarity in the spatial distribution of both aquatic vegetation and invertebrates and their response to some environmental characteristics emphasize the strong functional (as food preference, feeding and movement modalities) dependence of invertebrates from macrophytes on which they live.

According to the formulation of the European Water Framework Directive [16], the assessment of the biotic elements (phytoplankton, macrophytes and phytobenthos, benthic macroinvertebrates, fish) should include metrics on their taxonomic composition and abundance. As the sampling frequency and methods used were the same, in this paper we report a comparison between the plant-invertebrate communities of Lake Fibreno and some other central Italian lakes [20] [23]-[25] for the bioassessment of the ecological status in the littoral (Table 4). In addition to some macrophyte features, a series of bioindices were also considered for invertebrates. According to the results obtained from previous papers [54]-[56] we selected: the invertebrate species richness and Shannon diversity, ETOM (Ephemeropta + Trichoptera + Odonata + Mollusca), ETOC (Ephemeropta + Trichoptera + Odonata + Coleoptera) and LCrM (Large Crustacea + Mollusca). The comparative analysis along this lake series from Lake Bracciano to Lake Nemi (1981) shows a decreasing ecological quality of the macrophyte-invertebrates assemblage. Along this series Lake Fibreno displays a good environmental condition for all the metrics used. Finally we emphasize the real possibility to make in comparison a riverine lake with typical lentic lakes, as stressed by studies of other authors [57] and by a recent study on macroinvertebrates of Lake Piediluco [56].

\section{Conclusions}

Both vegetation and invertebrate communities of Lake Fibreno were well diversified and abundant, composed by a balanced mixing of typical species of lentic and lotic waters. Our results confirm that the lentic-lotic character of the lake represents one of the key driving factors determining most of the composition and spatial distribution of plants and their associated invertebrates. 
The comparison with other studied lakes in Central Italy indicates a good ecological condition of the littoral vegetation of Lake Fibreno in agreement to the high value of oxygen content and water transparency during the entire year, and this is mainly due to the large amount of pure source waters abundantly entering the lake. The impact of the high values of orthophosphates found in the lake and the presence of summer blooms of the sulfum-bacterium Thiopedia rosea, typically associated with anoxic fine sediments [58] [59], was controlled by the lotic character of the system, because nutrient uptake capability by organisms depends not only on the nutrient quantity but also on its permanence time in the ecosystem [60]. The continuous water flow produces an effect of dilution and fast water removal (washout), which hinders that a quote of nutrients could be intercepted by plants and invertebrates, maintaining the satisfactory ecological status in the lake.

Particular attention, however, must be addressed to the nutrient control reducing pointing source of domestic and agricultural discharges entering the lake to prevent deterioration and to maintain at least the present ecological status in agreement with its inclusion in a Natural Reserve of Special Area of Conservation of relevant habitats listed by the European Union Directive on the Conservation of Natural Habitats and of Wild Fauna and Flora (92/43/EEC). Some measures of the lake ecosystem protection and conservation should be undertaken. A regular monitoring of water quality should be considered and some additional parameters such as the characteristics of the sediments and the relevant biological elements according to the water Framework Directive [16] should periodically be monitored.

\section{Acknowledgements}

We are grateful to Francesca Pilotto (Leibniz Institute of Freshwater Ecology and Inland Fisheries, Berlin) for her contribution to the statistical analysis of data.

\section{References}

[1] Donohue, I., Donohue, L.A., Ní Ainín, B. and Irvine, K. (2009) Assessment of Eutrophication Pressure on Lakes Using Littoral Invertebrates. Hydrobiologia, 633, 105-122. http://dx.doi.org/10.1007/s10750-009-9868-8

[2] Kolada, A. (2010) The Use of Aquatic Vegetation in Lake Assessment: Testing the Sensitivity of Macrophyte Metrics to Anthropogenic Pressures and Water Quality. Hydrobiologia, 656, 133-147. http://dx.doi.org/10.1007/s10750-010-0428-z

[3] White, J. and Irvine, K. (2003) The Use of Mesohabitats and Their Macroinvertebrate Assemblages in the Ecological Assessment of Lakes. Aquatic Conservation: Marine and Freshwater Ecosystems, 13, 331-351. http://dx.doi.org/10.1002/aqc.586

[4] Brazner, J.C., Danz, N.P., Niemi, G.J., Regal, R.R., Trebitz, A.S., Howe, R.W., Hanowski, J.M., Johnson, L.B., Ciborowski, J.J.H. Johnston, C.A., Reavie, E.D., Brady, V.J. and Sgro, G.V. (2007) Evaluation of Geographic, Geomorphic and Human Influences on Great Lakes Wetland Indicators: A Multi-Assemblage Approach. Ecological Indicators, 7, 610-635. http://dx.doi.org/10.1016/j.ecolind.2006.07.001

[5] Taowu, M., Qinghui, H., Hai, W., Zijian, W., Chunxia, W. and Shengbiao, H. (2008) Selection of Benthic Macroinvertebrate-Based Multimetricsand Preliminary Establishment of Biocriteria for the Bioassessment of the Water Quality of Taihu Lake, China. Acta Ecologica Sinica, 28, 1192-1200. http://dx.doi.org/10.1016/S1872-2032(08)60038-4

[6] Coops, H., Kerkum, F.C.M., van den Berg, M.S. and van Splunder, I. (2007) Submerged Macrophyte Vegetation and the European Water Framework Directive: Assessment of Status and Trends in Shallow, Alkaline Lakes in the Netherlands. Hydrobiologia, 584, 395-402. http://dx.doi.org/10.1007/s10750-007-0586-9

[7] Hargeby, A. (1990) Macrophyte Associated Invertebrates and the Effect of Habitat Permanence. Oikos, 57, $338-346$. http://dx.doi.org/10.2307/3565963

[8] Jeppesen, E., Jensen, J. P., Søndergaard, M. and Lauridsen, T. (1997) Top-Down Control in Freshwater Lakes: The Role of Nutrient State, Submerged Macrophytes and Water Depth. Hydrobiologia, 342-343, 151-164. http://dx.doi.org/10.1023/A:1017046130329

[9] McGoff, E., Aroviita, J., Pilotto, F., Miler, O., Solimini, A.G., Porst, G., Jurca, T., Donohue, L. and Sandin, L. (2013) Assessing the Relationship between the Lake Habitat Survey and Littoral Macroinvertebrate Communities in European Lakes. Ecological Indicators, 25, 205-214. http://dx.doi.org/10.1016/j.ecolind.2012.09.018

[10] Miler, O., Porst, G., McGoff, E., Pilotto, F, Donohue, L., Jurca, T., Solimini, A.G., Sandin, L., Irvine, K., Aroviita, J., Clarke, R. and Pusch, M.T. (2013) Morphological Alterations of Lake Shores in Europe: A Multimetric Ecological Assessment Approach Using Benthic Macroinvertebrates. Ecological Indicators, 34, 398-410.

http://dx.doi.org/10.1016/j.ecolind.2013.06.002 
[11] Devine, J.A. and Vanni, M.J. (2002) Spatial and Seasonal Variation in Nutrient Excretion by Benthic Invertebrates in a Eutrophic Reservoir. Freshwater Biology, 47, 1107-1121. http://dx.doi.org/10.1046/j.1365-2427.2002.00843.x

[12] James, M.R., Weatherhead, M., Stanger, C. and Graynoth, E. (1998) Macroinvertebrate Distribution in the Littoral Zone of Lake Coleridge, South Island, New Zealand-Effect of Habitat Stability, Wind Exposure, and Macrophytes. New Zealand Journal Marine and Freshwater Researches, 32, 287-305. http://dx.doi.org/10.1080/00288330.1998.9516826

[13] Savage, A.A. (2000) Community Structure during a 27-Year Study of the Macroinvertebrate Fauna of a Chemically Unstable Lake. Hydrobiologia, 421, 115-127. http://dx.doi.org/10.1023/A:1003951223718

[14] Tolonen, K.T., Hämäläinen, H., Holopainen, I.J. and Karjalainen, J. (2001) Influences of Habitat Type and Environmental Variables on Littoral Macroinvertebrate Community in a Large Lake System. Archiv für Hydrobiologie, 152, 39-67.

[15] Vanni, M.J. (2002) Nutrient Cycling by Animals in Freshwater Ecosystems. Annual Review of Ecology and Systematics, 33, 341-370. http://dx.doi.org/10.1146/annurev.ecolsys.33.010802.150519

[16] WFD (2000) Council of European Communities. Directive 2000/60 EC of 23 October 2000 Establishing a Framework for Community Action in the Water Policy. Official Journal of the European Communities, L327/1.

[17] Mastrantuono, L. (1986) Community Structure of the Zoobenthos Associated with Submerged Macrophytes in the Eutrophic Lake Nemi (Central Italy). Bollettino di Zoologia, 53, 41-47. http://dx.doi.org/10.1080/11250008609355481

[18] Mastrantuono, L. (1990) Composition and Distribution of the Zoobenthos Associated with Submerged Macrophytes in Lake Albano (Italy) and Enviromental Quality in the Littoral. Rivista di Idrobiologia, 29, 709-727.

[19] Mastrantuono, L. (1991) Zoobenthos Associated with Subemerged Macrophytes in Littoral Areas of Lake Vico (Italy): Some Relations between Fauna Structure and Water Quality. Limnetica, 7, 153-162.

[20] Mastrantuono, L. (1993) Zoobenthos Associated with Submerged Macrophytes and Evaluation of Trophic Status in Lakes. Verhandlungen des Internationalen Verein Limnologie, 25, 780-783.

[21] Mastrantuono, L. and Mancinelli, T. (1999) Long-Term Changes of Zoobenthic Fauna and Submerged Vegetation in the Shallow Lake Monterosi (Italy). Limnologica, 29, 160-167. http://dx.doi.org/10.1016/S0075-9511(99)80063-2

[22] Mastrantuono, L. and Mancinelli, T. (2003) Meio-Macrobenthic Invertebrates Associated with Submerged Vegetation in a Chara-Lake (Lake Martignano, Italy). Atti Associazione Italiana Oceanolologia e Limnologia, 16, 187-201.

[23] Mastrantuono L. and Mancinelli, T. (2005) Littoral Zoobenthos Associated with Aquatic Plants and Bioassessment of Ecological Status in Lake Bracciano (Central Italy). Journal of Limnology, 64, 43-53. http://dx.doi.org/10.4081/jlimnol.2005.43

[24] Mastrantuono, L. and Sforza, M. (2008) Recovery Assessment in Lake Nemi (Italy) after a Twenty Year Period (19812001) Using Plant-Associated Invertebrates. Aquatic Ecosystem Health and Management, 11, 310-320. http://dx.doi.org/10.1080/14634980802093623

[25] Mastrantuono, L., Solimini, A.G., Nõges, P. and Bazzanti, M. (2008) Plant-Associated Invertebrates and Hydrological Balance in the Large Volcanic Lake Bracciano (Central Italy) during Two Years with Different Water Levels. Hydrobiologia, 599, 143-152. http://dx.doi.org/10.1007/s10750-007-9196-9

[26] Casella, L., Agrillo, E. and Spada, F. (2010) The Floating Island of Posta Fibreno: An Example of a Relic Mire in Central Italy. Annali di Botanica, 0, 105-113.

[27] D’Orsi, A. and Seminara, M. (2010) Dati preliminari di abbondanza e distribuzione di Salmo fibreni Zerunian \& Gandolfi 1990 nel bacino di Posta Fibreno (Italia Centrale): Primo utilizzo del visual census. Studi Trentini di Scienze Naturali, 87, 105-109.

[28] Zerunian, S. and Gandolfi, G. (1990) Salmo fibreni n. sp. (Osteichthyes, Salmonidae) endemica nel Bacino del Fibreno (Italia Centrale). Atti III Convegno AIIAD, Rivista di Idrobiologia, 29, 521-532.

[29] Angelini, M. and Lenzi, M. (1985) Indagine ecologica finalizzata alla determinazione del livello trofico delle acque del lago Fibreno. Comune di Posta Fibreno, Relazione Tecnica, 4 p.

[30] Montelucci, G. (1979) Aspetti botanici del lago di Posta-Fibreno (Lazio). Lavori della Società Italiana di Biogeografia, VI-1976, 263-278. (Tema: Il popolamento delle acque interne italiane)

[31] Casella, L., Spada, F. and Agrillo, E. (2008) Aspetti del paesaggio vegetale nel bacino del Fibreno. In: Atti I Giornata di Studio “Tutela e Conservazione dell'ecosistema acquatico Lago di Posta Fibreno area SIC/ZPS IT6050015”, 11-26.

[32] Di Vito, V., Mastrantuono, L., Agrillo, E. and Casella, L. (2005) Invertebrate Fauna, Aquatic Vegetation and PhysicoChemical Characteristics of a Lotic-Lentic System in a Natural Reserve (Lake Fibreno, Italy). SEFS4 (Fourth Symposium for European Freshwater Sciences), Krakow, 22-26 August 2005, 60.

[33] Oksanen, J., Kindt, R., Legendre, P. and O’Hara, R.B. (2006) Vegan: Community Ecology Package Version 1.17-4. 
http://cran.r-project.org/web/packages/vegan/index.html

[34] Sneath, P.H.A. and Sokal, R.R. (1973) Numerical Taxonomy: The Principles and Practice of Numerical Classification. W. H. Freeman, San Francisco, 573 p.

[35] Renkonen, O. (1938) Statisch-ökologische Untersuchungen über die terrestrische Käferwelt der finnischen Bruchmoore. Annales Zoologici Societatis Zoologicae-Botanicae Fennicae Vanamo, 6, 1-231.

[36] Takashi, A., Rajapakse, L. and Kanoh, M. (2010) Fine Sediment Retention as Affected by Annual Shoot Collapse: Sparganium erectum as an Ecosystem Engineer in a Lowland Stream. River Research and Applications, 26, 1153-1169. http://dx.doi.org/10.1002/rra.1322

[37] Caffrey, J.M. (1987) Macrophytes as Biological Indicators of Organic Pollution in Irish Rivers. In: Biological Indicators of Pollution, Royal Irish Academy, Dublin, 77-87.

[38] James, W.F., Best, E.P. and Barko, J.W. (2004) Sediment Resuspension and Light Attenuation in Peoria Lake: Can Macrophytes Improve Water Quality in This Shallow System? Hydrobiologia, 515, 193-201. http://dx.doi.org/10.1023/B:HYDR.0000027328.00153.b2

[39] Søndergaard, M. and Moss, B. (1998) Impact of Submerged Macrophytes on Phytoplankton in Shallow Freshwater Lakes. Ecological Studies, 131, 115-132. http://dx.doi.org/10.1007/978-1-4612-0695-8_6

[40] Vestergaard, O. and Sand-Jensen, K. (2000) Aquatic Macrophytes Richness in Danish Lakes in Relation to Alkalinity, Transparency, and Lake Area. Canadian Journal of Fisheries and Aquatic Sciences, 57, 2022-2031. http://dx.doi.org/10.1139/f00-156

[41] Wetzel, R.G. (2001) Fundamental Processes within Natural and Constructed Wetland Ecosystems: Short-Term versus Long-Term Objectives. Water Science and Technology, 44, 1-8.

[42] Blindow, I., Hargeby, A. and Andersson, G. (2002) Seasonal Changes of Mechanisms Mantaining Clear Water in a Shallow Lake with Abundant Chara Vegetation. Aquatic Botany, 72, 315-334. http://dx.doi.org/10.1016/S0304-3770(01)00208-X

[43] Penning, W.E., Mjelde, M., Dudley, B., Hellsten, S., Hanganu, J., Kolada, A., van den Berg, M., Poikane, S., Phillips, G., Willby, N. and Ecke, F. (2008) Classifying Aquatic Macrophytes as Indicators of Eutrophication in European Lakes. Aquatic Ecology, 42, 237-251. http://dx.doi.org/10.1007/s10452-008-9182-y

[44] Pereyra-Ramos, E. (1981) The Ecological Role of Characeae in the Lake Littoral. Ekologia Polska, 29, 167-209.

[45] Van den Berg, M.S., Coops, H., Noordhuis, R., van Schie, J. and Simons, J. (1997) Macroinvertebrate Communities in Relation to Submerged Vegetation in Two Chara Dominated Lakes. Hydrobiologia, 342-343, 143-150. http://dx.doi.org/10.1023/a:1017094013491

[46] Saether, O.A. (1979) Chironomid Communities as Water Quality Indicators. Ecography, 2, 65-74. http://dx.doi.org/10.1111/j.1600-0587.1979.tb00683.x

[47] Seire, A. and Pall, P. (2000) Chironomid Larvae (Diptera, Chironomidae) as Indicators of Water Quality in Estonian Streams. Proceedings of the Estonian Academy of Sciences: Biology, Ecology, 49, 307-316.

[48] Mouthon, J. (1981) Molluscs and Biodegradable Pollution in Rivers: Studies into the Limiting Values of 11 PhysicoChemical Variables. Hydrobiologia, 319, 57-63. http://dx.doi.org/10.1007/BF00020971

[49] Sládeček, V. (1973) System of Water Analysis from the Biologica Point of View. Archiv für Hydrobiologie-Beiheft Ergebnisse der Limnologie, 7, 1-218.

[50] Verdonschot, P.F.M. (1996) Oligochaetes and Eutrophication; An Experiment over Four Years in Outdoor Mesocosms. Hydrobiologia, 334, 169-183. http://dx.doi.org/10.1007/BF00017367

[51] O.E.C.D. (Organization for Economic Cooperation and Development) (1982) Eutrophication of Waters, Monitoring, Assessment and Control. O.E.C.D., Parigi.

[52] Hynes, H.B.N. (1970) The Ecology of Running Waters. University of Toronto Press, Toronto, 555 pp.

[53] Timm, H., Käiro, K., Möls, T. and Virro, T. (2011) An Index to Assess Hydromorphological Quality of Estonian Surface Waters Based on Macroinvertebrate Taxonomic Composition. Limnologica, 41, 398-410. http://dx.doi.org/10.1016/j.limno.2011.09.006

[54] Bazzanti, M., Mastrantuono, L. and Solimini, A.G. (2012) Selecting Macroinvertebrate Taxa and Metrics to Assess Eutrophication in Different Depth Zones of Mediterranean Lakes. Fundamental and Applied Limnology, 180, 133-143. http://dx.doi.org/10.1127/1863-9135/2012/0200

[55] Burton, T.M., Uzarski, D.G., Gathman, J.P., Genet, J.A., Keas, B.E. and Stricker, C.A. (1999) Development of Preliminary Invertebrate Index of Biotic Integrity for Lake Huron Coastal Wetlands. Wetlands, 19, 869-882. http://dx.doi.org/10.1007/BF03161789

[56] Mastrantuono, L., Pilotto, F., Rossopinti, A., Bazzanti, M. and Solimini, A.G. (2014) Response of Littoral Macroin- 
vertebrates to Morphological Disturbances in Mediterranean Lakes: The Case of Lake Piediluco (Central Italy). Fundamental and Applied Limnology. (Submitted)

[57] Timm, H. and Möls, T. (2008) Do Shallow-Water Macroinvertebrate Assemblages Correspond to Physico-Chemical Habitats of Streams and Lakes? Verhandlungen des Internationalen Verein Limnologie, 31, 138-140.

[58] Gomes, E.A.T. and Godinho, M.J.L. (2003) Structure of the Protozooplankton Community in a Tropical Shallow and Eutrophic Lake in Brazil. Acta Oecologica, 24, S153-S161. http://dx.doi.org/10.1016/S1146-609X(03)00039-0

[59] Steenbergen, C.L.M. and Korthals, H.J. (1982) Distribution of Phototrophic Microorganisms in the Anaerobic and Microaerophilic Strata of Lake Vechten (The Netherlands). Pigment Analysis and Role in Primary Production. Limnology and Oceanography, 27, 883-895.

[60] Balls, H., Moss, B. and Irvine, K. (1989) The Loss of Submerged Plants with Eutrophication I. Experimental Design, Water Chemistry, Aquatic Plant and Phytoplankton Biomass in Experiments Carried out in Ponds in the Norfolk Broadland. Freshwater Biology, 22, 71-87. http://dx.doi.org/10.1111/j.1365-2427.1989.tb01085.x 
Scientific Research Publishing (SCIRP) is one of the largest Open Access journal publishers. It is currently publishing more than 200 open access, online, peer-reviewed journals covering a wide range of academic disciplines. SCIRP serves the worldwide academic communities and contributes to the progress and application of science with its publication.

Other selected journals from SCIRP are listed as below. Submit your manuscript to us via either submit@scirp.org or Online Submission Portal.
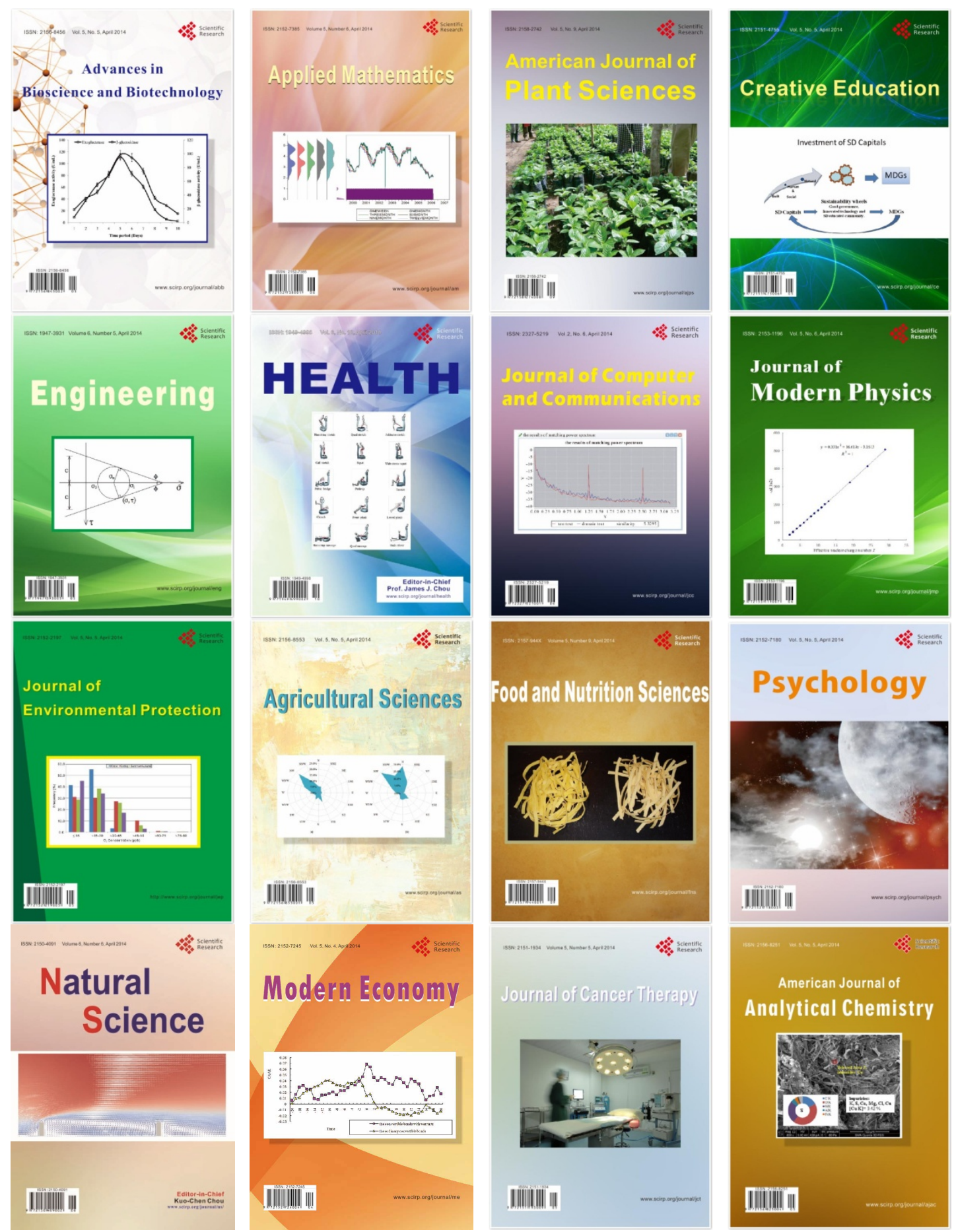